\title{
ANALISIS TRIWULANAN: \\ Perkembangan Moneter, Perbankan dan Sistem Pembayaran, Triwulan I - 2009
}

\author{
Tim Penulis Laporan Triwulanan, Bank Indonesia
}

Terus memburuknya perekonomian global semakin dirasakan dampaknya pada perekonomian domestik selama triwulan I-2009. Hal tersebut mengakibatkan perekonomian Indonesia diperkirakan tumbuh lebih lambat dari perkiraan. Perlambatan tersebut selain disebabkan oleh kinerja ekspor yang turun, juga dikarenakan mulai melemahnya daya beli masyarakat. Meski demikian, berlangsungnya aktivitas ekonomi selama dilakukannya pesta demokrasi dalam rangka Pemilihan Umum, diperkirakan mampu menahan lebih jauh perlambatan ekonomi domestik. Ke depan, pada tahun 2009 perekonomian masih dihadapkan pada ketidakpastian pemulihan ekonomi global sehingga perekonomian Indonesia diperkirakan tumbuh lebih rendah dari yang diperkirakan pada awal tahun sebesar 4,0-5,0\%. Dengan mempertimbangkan perkembangan dan prospek perekonomian tersebut, pada April 2009, Bank Indonesia kembali menurunkan BI Rate sebesar 25 bps menjadi 7,5\%. Penurunan BI Rate ini adalah kali kelima sejak Desember 2008. Secara akumulatif (Des 08-April 09), BI Rate telah turun sebesar 175 bps.

Selama triwulan I-2009, pertumbuhan ekonomi diprakirakan sebesar 4,6\%. Dari sisi pengeluaran, seluruh komponen pertumbuhan mengalami perlambatan terutama ekspor. Namun demikian, aktivitas ekonomi selama berlangsungnya pesta demokrasi yang ditandai oleh kampanye partai politik dan pelaksanaan pemilu di seluruh Indonesia, diperkirakan dapat mencegah perlambatan konsumsi masyarakat yang lebih dalam. Di sisi sektoral, sektor-sektor yang diperkirakan mengalami perlambatan tajam adalah sektor industri dan pertambangan. Sementara itu sektor-sektor yang non-tradable seperti pengangkutan dan komunikasi serta sektor listrik, gas dan air bersih masih akan tumbuh tinggi dengan tren yang melambat. Apabila dilihat secara regional, anjloknya ekspor sangat berpengaruh terhadap perlambatan ekonomi di beberapa daerah, seperti Sumatera, Kalimantan, Sulawesi, Maluku, dan Papua.

Kecenderungan penurunan tekanan inflasi terus berlanjut. Tekanan inflasi selama triwulan I-2009 masih cenderung menurun mencapai 0,36\% (secara triwulanan, qtq) atau 7,92\% (secara 
tahunan, yoy). Penurunan tekanan inflasi tersebut terutama disebabkan oleh masih berlanjutnya dampak langsung dan tidak langsung dari penurunan BBM. Selain itu membaiknya ekspektasi inflasi serta melemahnya permintaan domestik juga menjadi penyumbang dari rendahnya tekanan inflasi. Sementara itu, tekanan dari harga-harga barang yang dikendalikan pemerintah (administered prices) dan harga makanan bergejolak (volatile food) juga masih rendah terkait dengan terjaganya produksi pangan domestik.

Di sisi eksternal, Neraca Pembayaran Indonesia pada triwulan I-2009 diperkirakan mencatat surplus sebesar 3,5 miliar dolar AS. Volume ekspor beberapa komoditas unggulan seperti minyak sawit, tembaga, dan kertas, tetap menunjukkan kinerja yang positif. Adapun beberapa komoditas seperti batu bara dan produk kimia mengalami penurunan seiring dengan melemahnya permintaan global. Sementara itu, impor tercatat mengalami penurunan baik impor bahan baku maupun bahan modal untuk industri di dalam negeri, seiring dengan melemahnya permintaan domestik. Sementara itu, di neraca finansial, penerbitan global bond oleh pemerintah telah menyebabkan neraca finansial mencatat surplus. Dengan kondisi tersebut, posisi cadangan devisa pada triwulan I-2009 diperkirakan menjadi 54,8 miliar dolar AS atau setara dengan 5,9 bulan impor dan pembayaran utang luar negeri (ULN) pemerintah.

Di pasar keuangan, tekanan terhadap pasar keuangan dirasakan masih terus berlangsung walaupun membaik di akhir triwulan. Tekanan tersebut terkait dengan kinerja perusahaanperusahaan yang belum membaik, dan masih tingginya persepsi risiko para pemilik modal. Namun, di penghujung triwulan I-2009, muncul sentimen positif di pasar keuangan sehubungan dengan bertambahnya cadangan devisa terkait dengan penerbitan global bond Pemerintah RI, peningkatan jumlah Bilateral Swap Arrangement (BSA) dengan Pemerintah Jepang, dan penandatanganan Bilateral Currency Swap Arrangement (BCSA) dengan Bank Sentral China.

Di tengah kondisi perekonomian global yang kian memburuk, serta seiring dengan melemahnya tekanan inflasi, Bank Indonesia tetap mengarahkan perhatian pada upaya menjaga pertumbuhan ekonomi dan menghindari terjadinya penurunan daya beli masyarakat yang semakin dalam. Berbagai kebijakan moneter Bank Indonesia ditempuh dalam rangka mendukung bangkitnya sektor riil, khususnya UMKM, guna mendukung pertumbuhan ekonomi negeri.

Selain melakukan pelonggaran kebijakan moneter, paket suplemen kebijakan Bank Indonesia lainnya yang dapat dilakukan adalah mempercepat penyaluran kredit perbankan dan menurunkan risiko kredit. Beberapa paket tambahan dilakukan oleh Bank Indonesia berupa early restructuring perbankan, meminta adanya penjaminan Pemerintah terhadap kredit untuk proyek-proyek strategis seperti air minum, listrik, perumahan, serta infrastruktur jalan dan jembatan, yang pembangunannya dibiayai oleh APBN, serta memfasilitasi pertemuan perbankan 
dengan sektor-sektor yang berpotensi mendorong peningkatan intermediasi perbankan. Upaya memfokuskan kegiatan usaha bank ke UMKM dan linkage program antara bank umum dan bank perkreditan rakyat (BPR), atau lembaga keuangan mikro, seperti koperasi dan baitul maal wa tamwil (BMT), terus dilakukan dengan gencar. Hal tersebut diharapkan dapat mendukung kehidupan masyarakat dan mencegah terjadinya perlambatan lebih dalam pada perekonomian.

Ke depan, perekonomian Indonesia tahun 2009 akan sangat dipengaruhi oleh dinamika perekonomian global. Pertumbuhan ekonomi Indonesia tahun 2009 diperkirakan berada lebih rendah dari perkiraan awal tahun sebesar 4,0-5,0\%. Meski demikian, Bank Indonesia memperkirakan bahwa pertumbuhan harga komoditas intenasional saat ini telah mencapai titik terendah sehingga terdapat tanda-tanda pembalikan yang dapat mendorong perbaikan harga-harga, dan pada gilirannya mendukung pertumbuhan ekspor. Di sisi lain, semakin melambatnya perekonomian dunia, dan menurunnya permintaan agregat, terus mendorong turunnya tekanan inflasi. Ke depan, pada tahun 2009, dengan prospek pertumbuhan ekonomi yang diperkirakan terus melambat, tren inflasi diperkirakan akan berada pada batas bawah kisaran $5 \%-7 \%$.

Di sisi perbankan, industri perbankan dalam negeri diprakirakan akan mengalami dampak dari krisis keuangan global dan perlambatan pertumbuhan ekonomi. Namun secara umum, perbankan nasional masih tetap memiliki daya tahan yang cukup baik, yang tercermin dari indikator utama perbankan CAR dan NPL. Rasio kecukupan modal (CAR) masih tetap tinggi yakni 17,7\%. Kondisi likuiditas perbankan juga mengalami peningkatan sejalan dengan tingginya peningkatan Dana Pihak Ketiga (DPK) sebesar 19,8\%. Namun, tren perlambatan pertumbuhan kredit masih berlangsung terkait dengan sikap kehati-hatian perbankan dalam kondisi ketidakpastian terhadap prospek ekonomi.

Dengan mempertimbangkan berbagai perkembangan tersebut di atas, Dewan Gubernur Bank Indonesia pada April 2009 memutuskan untuk menurunkan BI Rate sebesar 25 bps menjadi 7,50 \%. Bank Indonesia akan senantiasa mengarahkan kebijakan moneter yang kondusif bagi permintaan domestik dengan tetap berkomitmen untuk menjaga stabilitas ekonomi dalam jangka menengah panjang. Secara operasional, ruang penurunan BI Rate ke depan masih terbuka jika prospek inflasi tetap mengarah pada sasaran inflasi jangka menengah. Di bidang perbankan, Bank Indonesia akan terus berupaya untuk melanjutkan langkah dalam mewujudkan perbankan yang sehat, kuat dan kompetitif. Di samping itu, upaya meningkatkan kehati-hatian industri perbankan dalam melewati krisis global senantiasa menjadi perhatian Bank Indonesia. 